\title{
Hubungan Antara Konsentrasi Testosteron, Lingkar Skrotum, Libido dan Kuantitas Sperma Pejantan Sapi Pasundan
}

\author{
(CORRELATION AMONG TESTOSTERONE CONCENTRATIONS, SCROTAL \\ CIRCUMFERENCE, LIBIDO, AND SPERM QUANTITY IN PASUNDAN BULLS)
}

\author{
Santoso ${ }^{1,2^{*}}$, Herdis ${ }^{2}$, Raden Iis Arifiantini ${ }^{3}$, \\ Asep Gunawan ${ }^{4}$, Cece Sumantri ${ }^{4}$
}

\author{
${ }^{1}$ Program Studi Ilmu Produksi dan Teknologi Peternakan, \\ Fakultas Peternakan, IPB University, \\ Jl Agathis, Kampus IPB, Dramaga, Bogor, \\ Jawa Barat, Indonesia. 16680 \\ ${ }^{2}$ Pusat Teknologi Produksi Pertanian, \\ Badan Riset Inovasi Nasional (BRIN), Jakarta, Indonesia. \\ ${ }^{3}$ Departemen Klink, Reproduksi dan Patologi, \\ Fakultas Kedokteran Hewan, IPB University. \\ ${ }^{4}$ Departemen Ilmu Produksi dan Teknologi Peternakan, \\ Fakultas Peternakan, IPB University \\ *Email: santoso.drh@gmail.com
}

\begin{abstract}
ABSTRAK
Sapi pasundan merupakan salah satu sumber daya genetik sapi potong lokal Indonesia yang perlu dikembangkan dan dilestarikan. Penelitian bertujuan untuk menganalisis hubungan konsentrasi testosteron, lingkar skrotum, libido, dan kuantitas sperma pada sapi pejantan pasundan. Sepuluh ekor sapi pasundan berumur 3-6 tahun dengan bobot badan (BB) 380-430 kg digunakan pada penelitian. Konsentrasi hormon testosteron dianalisa dengan metode enzyme-linked immunosorbent assay (ELISA). Libido diamati dari waktu pejantan didekatkan ke kandang atau tempat koleksi semen hingga kontak pertama dengan betina (courtship), waktu pejantan melakukan percumbuan (dating) sampai menaiki betina (mounting), waktu pejantan dating dan pertama kali menaiki betina sampai terjadi ejakulasi. Pengukuran lingkar skrotum menggunakan pita ukur. Semen dikoleksi menggunakan vagina buatan dan dievaluasi karakteristik volume semen dan konsentrasi sperma. Data dianalisa dengan korelasi regresi linear. Rataan konsentrasi testosteron adalah 13,38 $\pm 0,21 \mathrm{ng} / \mathrm{mL}$. Konsentrasi testosteron $(\mathrm{r}=-0,661)$ dan umur $(\mathrm{r}=0,681)$ menunjukkan korelasi negatif dengan waktu courtship $(\mathrm{P}<0,05)$, waktu mounting berkorelasi positif dangan waktu ejakulasi $(\mathrm{r}=0,756, \mathrm{P}<0,05)$. Korelasi tidak ditemukan antara konsentrasi testosteron dengan umur $(r=0.116)$, lingkar skrotum $(r=0.328)$, peningkatan $(r=0.249)$, ejakulasi $(r=-0.179)$, volume semen $(r=0.243)$, dan konsentrasi sperma $(r=-0.116)$. Penelitian menyimpulkan konsentrasi testosteron dan umur berkorelasi negatif dengan courtship dan waktu mounting berkorelasi positif dangan waktu ejakulasi.
\end{abstract}

Kata-kata kunci: sapi pasundan; testosterone; libido; sperma

\begin{abstract}
Pasundan cattle are one of the Indonesian domestic resources of genetic bull that need to be developed and conserved. This study aimed to analyze the correlation between testosterone concentrations, scrotal circumference, libido, and sperm quantity in Pasundan bulls. A total of 10 Pasundan bulls aged 3-6 years with body weight (BW) 380-430 kg were used in this study. Testosterone concentration was measured by enzyme-linked immunosorbent assay (ELISA) method. Libido was measured in terms of time taken for the entering arena until the first contact with the teaser (courtship), time taken from dating until mounting the teaser (mounting), and time taken from dating and the first mounting until ejaculation (ejaculation).
\end{abstract}


Measurement of scrotal circumferences were obtained by using scrotal measuring tape. Semens were collected by using artificial vagina and evaluated for physical characteristics namely semen volume and sperm concentration. Data were analyzed using correlation-regresion test. The mean value for serum testosterone concentration was $13.38 \pm 0.21 \mathrm{ng} / \mathrm{mL}$. Testosterone concentrations $(\mathrm{r}=-0.661)$ and age $(\mathrm{r}=0.681)$ showed a negative correlation with scrotal courtship $(\mathrm{P}<0.05)$, mounting showed a positive correlation with ejaculation $(\mathrm{r}=0.756, \mathrm{P}<0.05)$. No correlation, however, was found between testosterone concentrations with age $(r=0.116)$, scrotal circumference $(r=0.328)$, mounting $(r=0.249)$, ejaculation $(r=-0.179)$, semen volume $(\mathrm{r}=0.243)$, and sperm concentration $(\mathrm{r}=-0.116)$. It can be concluded that testosterone concentrations and age correlated negatively witih courtship, and mounting correlated positively with ejaculation.

Key words: pasundan cattle; testosterone; libido; sperm

\section{PENDAHULUAN}

Indonesia kaya akan sumber daya genetik (SDG) termasuk SDG ternak sapi, salah satunya sapi pasundan. Rumpun sapi pasundan telah ditetapkan melalui Keputusan Menteri Pertanian Nomor 1051/Kpts/SR.120/10/2014 sebagai sumber daya genetik ternak Indonesia (Kementan, 2014). Perkawinan sapi pasundan umumnya dilakukan dengan kawin alam. Perkawinan banyak terjadi saat sapi digembalakan baik di padang penggembalaan maupun di kawasan hutan (Nugraha, 2016).

Perbaikan mutu genetik sapi pasundan saat ini dilakukan melalui program Inseminasi Buatan (IB) menggunakan semen beku pejantan unggul. Persyaratan yang harus dipenuhi calon pejantan unggul adalah ternak sehat dan bebas dari penyakit hewan menular strategis, organ reproduksi normal, tidak cacat serta mempunyai karakteristik (konformasi dan sifat kualitatif) sesuai dengan kriteria rumpun (Ditjennak, 2018). Seleksi pejantan dilakukan dengan Breeding Soundness Examination (BSE) meliputi kesehatan fisik, tingkah laku seksual (libido) dan mampu mengeluarkan sperma berkualitas kepada betina yang dilayani (Barth, 2018).

Fertilitas sangat penting dalam seleksi pejantan. Barth (2018) menyatakan bahwa fertilitas pada pejantan dapat diketahui berdasarkan kapasitas produksi sperma yang diprediksi melalui kadar testosteron dan lingkar skrotum. Sperma dibentuk oleh sel epitel di dalam tubulus seminiferus testis, tahapan ini disebut spermatogenesis (Senger, 2012). Kadar testosteron pada darah dan jaringan testis memiliki peran penting dalam proses spermatogenesis (Senger, 2012; Smith dan Walker, 2014; Barth, 2018;). Testis dibungkus oleh skrotum yang mencerminkan ukuran testis dan menyatakan banyaknya jaringan atau tubulus seminiferus (Perumal, 2014; Wiyanto et al., 2014). Korelasi positif antara konsentrasi testosteron dengan kualitas sperma dan fertilitas telah dilaporkan pada sapi kuantan (Anwar dan Jiyanto, 2019), kerbau simeulue (Qadarsina et al., 2019), kambing peranakan ettawa (Rachmawati et al. 2014; Hendri er al., 2017), kambing bligon dan kejobong (Rachmawati et al. 2014), tetapi korelasi tersebut tidak ditemukan pada domba (Moghaddam et al., 2012).

Data korelasi konsentrasi testosteron dengan beberapa parameter reproduksi pada sapi pasundan belum pernah dilaporkan. Penelitian ini dilakukan bertujuan untuk mengetahui hubungan antara konsentrasi testosteron, libido dan kuantitas semen sapi pejantan pasundan. Hal ini penting sebagai informasi dasar untuk memperkaya data reproduksi pada sapi pejantan pasundan.

\section{METODE PENELITIAN}

\section{Hewan Percobaan}

Prosedur yang dilakukan dalam penelitian ini telah mendapatkan persetujuan dari Komite Etik Hewan Fakultas Kedokteran Hewan IPB University (Ethical Approval No: 161 / KEH / SKE / VII / 2019). Penelitian ini menggunakan 10 ekor sapi pasundan berumur 5-8 tahun dengan bobot badan (BB) 380-430 kg. Pakan diberikan pada pagi dan sore hari berupa hijauan segar (10\% per ekor per hari) dan konsentrat (1\% per ekor per hari) dari bobot badan (BB), dan air minum diberikan ad libitum.

\section{Volume dan Konsentrasi Semen}

Semen dikoleksi menggunakan vagina buatan (VB) dua kali dalam seminggu, dilaksanakan pada pagi hari sesuai dengan Standar Operasional Prosedur (SOP) dari Balai Inseminasi Buatan Daerah (BIBD) Ciamis Jawa Barat. Semen dibawa ke laboratorium untuk 
dievaluasi secara makroskopis dan mikroskopis yang mengacu pada Arifiantini (2012). Volume semen merupakan volume ejakulat yang diperoleh dari tabung koleksi semen VB. Konsentrasi sperma adalah jumlah sperma dalam $1 \mathrm{~mL}$ semen dihitung menggunakan fotometer (Photometer SDM $6^{\circledR}$, Minitub $\mathrm{GmbH}$, Tiefenbach, Germany).

\section{Lingkar Skrotum}

Pengukuran lingkar skrotum dilakukan pada waktu siang hari saat suhu lingkungan tinggi karena berpengaruh terhadap turunnya testis ke dalam skrotum. Pengukuran lingkar skrotum menggunakan pita ukur (Sorensen, 1979) dengan melingkarkan ke pangkal skrotum kemudian turun sampai bagian tengah pada bagian terlebar lingkar skrotum.

\section{Libido}

Libido diamati berdasarkan interval kopulasi dengan pengujian terhadap waktu (detik) pertama kali jantan bereaksi atau berespons mendekati betina (Hoflack et al., 2006). Observasi dilakukan berdasarkan modifikasi metode Hoflack et al. (2006) dan Singh et al. (2015) dengan cara mengamati waktu respons pejantan melalui hasil rekaman video (Sony HDR-CX405 ${ }^{\circledR}$, Sony Co, China) meliputi jarak tempuh (courtship), waktu reaksi (mounting), dan ejakulasi. Courtship merupakan waktu yang dihitung sejak pejantan didekatkan ke zona tempat koleksi semen hingga kontak pertama dengan betina yang berjarak delapan meter. Mounting adalah waktu pejantan melakukan percumbuan (dating) sampai menaiki betina. Ejakulasi adalah proses pengeluaran semen dalam organ reproduksi betina atau VB, waktu dihitung mulai pejantan dating dan pertama kali menaiki betina sampai terjadi ejakulasi (Senger, 2012).

\section{Hormon Testosteron}

Konsentrasi hormon testosteron dianalisis dengan metode enzyme-linked immunosorbent assay (ELISA, EIA-1559 ${ }^{\circledR}$, DRG International Inc., New Jersey, Amerika Serikat) diukur menggunakan microplate (Microplate MP96 UV $^{\circledR}$, Safas, Monaco, Monaco) di LAPTIAB, Puspiptek Serpong. Sampel darah diambil pada vena coccygea menggunakan tabung vakum darah plain. Darah disentrifugasi pada $1.750 \mathrm{rpm}$ selama 10 menit untuk memperoleh serum, kemudian dituang ke dalam tabung microtube $2 \mathrm{~mL}$ dan disimpan pada suhu $-20^{\circ} \mathrm{C}$.

\section{Analisis Statistika}

Data konsentrasi testosteron, umur, lingkar skrotum, libido (courtship, mounting, ejakulasi), volume semen, dan konsentrasi spermatozoa disajikan dalam bentuk tabel dengan rataan \pm simpangan baku. Korelasi antar parameter dianalisa dengan regresi linear menggunakan program SPSS versi 26.

\section{HASIL DAN PEMBAHASAN}

\section{Konsentrasi Testosteron, Lingkar Skro- tum, Libido dan Kuantitas Sperma}

Hasil penelitian menunjukkan konsentrasi hormon testosteron pada sapi pasundan dengan rataan umur $77,18 \pm 6,51$ bulan sebesar $13,38 \pm 0,21 \mathrm{ng} / \mathrm{mL}$. Konsentrasi hormon ini lebih tinggi dibandingkan dengan sapi peranakan

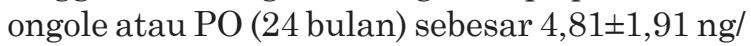
$\mathrm{mL}$ (Affandhy et al., 2018), sapi kuantan (24-36 bulan) sebesar 2,82 $\pm 1,99 \mathrm{ng} / \mathrm{mL}$ (Anwar dan Jiyanto, 2019), sapi silangan Friesian Holstein (FH) dengan harparkar (48-72 bulan) sebesar $7,06 \pm 1,50 \mathrm{ng} / \mathrm{mL}$ (Rajak et al., 2014), dan sapi cholistani (60-132 bulan) sebesar 5,81 $\pm 0,32 \mathrm{ng} /$ $\mathrm{mL}$ (Mahmood et al., 2013). Testosteron yang dihasilkan oleh sel-sel Leydig testis berperan sangat penting untuk memelihara spermatogenesis (Smith dan Walker, 2014). Variasi konsentrasi testosteron darah dapat disebabkan oleh banyak faktor seperti ras, iklim, ransum dan usia (Affandhy et al., 2018; Qadarsina et al., 2019) serta sensitivitas dan akurasi metode pengukuran yang digunakan (Pineda dan Dooley, 2003).

Pengukuran lingkar skrotum sapi pasundan diperoleh rataan $30,10 \pm 1,39 \mathrm{~cm}$. Hasil ini lebih rendah jika dibandingkan dengan sapi PO (36-72 bulan) sebesar 40,11 cm (Muthiapriani et al., 2019). Perbedaan lingkar skrotum dimungkinkan akibat adanya perbedaan umur (Perumal, 2014) dan bangsa (Menegassi et al., 2011; Eriksson et al., 2012). Wiyanto et al. (2014) menyatakan bahwa ukuran testis akan terus meningkat sejalan dengan bertambahnya umur. Libido terbagi menjadi tiga tahapan yaitu sebelum kopulasi, kopulasi dan setelah kopulasi. Pada domba, kambing dan sapi memiliki tipe kopulasi pendek, sedangkan kopulasi panjang terjadi pada babi dan kuda (Senger, 2012). Hasil pengukuran libido sapi pasundan memperlihatkan rataan waktu courtship selama $8,8 \pm 1,90$ detik, mounting selama 70,3 $\pm 28,05$ detik, dan ejakulasi selama 146,4 $\pm 20,26$ detik. 
Waktu courtship pada sapi pasundan lebih lama jika dibandingkan dengan sapi bali (24-36 bulan) yaitu 3,25 detik (Knaofmone et al., 2019).

Penelitian yang dilakukan oleh Sholikah et al. (2018) pada sapi brahman (60-96 bulan) melaporkan terjadinya mounting setelah 218,1 detik, lebih lama jika dibandingkan dengan sapi pasundan pada umur yang sama. Waktu mounting yang lama juga dilaporkan pada sapi pejantan limousin dan simmental berumur 72 108 bulan yaitu 214,37 detik dan 302,45 detik (Sam et al., 2017). Ejakulasi pada sapi pasundan lebih cepat terjadi jika dibandingkan dengan hasil penelitian Hoflack et al. (2006) pada sapi FH dan belgian blue (BB), serta Sholikah et al. (2018) pada sapi brahman. Rataan ejakulasi sapi FH (11,5-17,2 bulan) selama 150,32 detik, sapi BB (<24 bulan) selama 175,18 detik, sapi BB (24-48 bulan) selama 186,60 detik, dan sapi BB (> 48 bulan) selama 335,67 detik. Ejakulasi pada sapi brahman terjadi selama 199,8 detik (36 bulan), 540 detik ( 60 bulan), dan 698,4 detik (96 bulan). Perbedaan waktu courtship, mounting, dan ejakulasi dapat terjadi akibat adanya perbedaan umur dan bangsa sapi (Rehman et al., 2016). Hasil penelitian Ahmad et al. (2005) melaporkan bahwa sapi sahiwal memiliki perbedaan signifikansi libido pada umur $<36$ bulan, 36-60 bulan, dan $>60$ bulan.

Libido dan kemampuan kawin ternak jantan berhubungan erat dengan efisiensi pejantan dalam melakukan perkawinan. Pejantan berlibido rendah memiliki kinerja reproduksi yang kurang efisien (Herdis, 2012). Variasi tingkah laku seksual antar individu dapat disebabkan oleh faktor internal yaitu genetik, umur ternak dan kondisi fisiologis (Ahmed et al., 2005; Sholikah et al. 2018) maupun eksternal meliputi lingkungan, musim, pemberian pakan dan manajemen (Ahmed et al. 2005; Sam et al., 2017; Sholikah et al., 2018). Lebih lanjut Rehman et al. (2016) menyatakan bahwa libido dan kualitas semen pada sapi jersey akan terus meningkat seiring pertambahan umur sampai sapi berumur 96 bulan.

Volume semen dalam penelitian ini lebih tinggi $(6,67 \pm 0,89 \mathrm{~mL})$ dibandingkan dengan volume semen sapi pasundan hasil penelitian Darussalam et al. (2020) sebesar 4,66 mL. Volume semen sapi pasundan ini hampir sama dengan volume semen sapi asli Indonesia yaitu sapi bali antara $6,32 \pm 0,07 \mathrm{~mL}$ (Indriastuti et al., 2020) dan 6,44 $\pm 0,23 \mathrm{~mL}$ (Nabilla et al., 2018). Volume semen sapi pasundan sedikit lebih tinggi dari volume semen sapi madura yaitu sebesar
$5,54 \pm 1,64 \mathrm{~mL}$ pada musim hujan dan 5,62 $\pm 1,47$ $\mathrm{mL}$ pada musim kemarau (Komariah et al., 2020) ataupun sapi aceh 3,82 $\pm 0,47 \mathrm{~mL}$ (Zulyazaini et al., 2016).

Konsentrasi sperma pejantan pasundan pada penelitian ini cukup rendah $(790,9 \pm 65,64$ $10^{6} \mathrm{~mL}-1$ semen) jika dibandingkan dengan kisaran normal konsentrasi sperma pejantan dewasa yaitu 800 sampai $1.200 \times 10^{6} \mathrm{~mL}-1$ semen (Campbell et al., 2003). Konsentrasi sperma sapi pasundan pada penelitian ini juga lebih rendah dibandingkan dengan sapi bali $1.164,81 \times 10^{6} \mathrm{~mL}$ 1 (Indriastuti et al., 2020), sapi SO 1.256,42 \pm 208,34×10 6 mL-1 (Maulana et al., 2019), sapi PO $1.286 \times 10^{6} \mathrm{~mL}-1$ dan sapi madura $1.076 \pm 127,634 \times 10^{6} \mathrm{~mL}-1$ (Ratnawati et al., 2018).

\section{Hubungan antara Konsentrasi Testos- teron, Lingkar Skrotum, Libido dan Kuantitas Sperma \\ Korelasi antara konsentrasi hormon,} lingkar skrotum, libido dan kuantitas sperma disajikan pada Tabel 2. Hasil penelitian menunjukkan korelasi yang rendah $(\mathrm{P}>0,05)$ antara konsentrasi hormon dengan umur $(0,116)$, lingkar skrotum $(0,382)$, mounting $(0,429)$, ejakulasi $(-0,179)$, volume semen $(0,243)$, dan konsentrasi sperma $(-0,116)$. Korelasi tidak nyata antara konsentrasi testosteron dengan volume semen dan konsentrasi sperma juga dilaporkan oleh Rajak et al. (2014) pada sapi persilangan (FH X tharparkar).

Ramaswamy dan Weinbauer (2014) melaporkan bahwa luteinizing hormone (LH), testosteron, dan follicle stimulating hormone (FSH) merupakan faktor endokrin penting yang mengendalikan fungsi testis. Variasi konsentrasi testosteron sangat dipengaruhi oleh spesies, ras, individu pejantan, usia, musim, stimulus eksternal, lingkungan, dan waktu koleksi semen (Rajak et al., 2014). Testosteron memiliki specific site dalam hal menginisiasi (Haywood et al., 2003), memelihara dan pemulihan atau restorasi dari semua fase spermiogenesis (Hasbi dan Gustina, 2018). Testosteron memiliki peran penting dalam proses spermatogenesis (Hasbi dan Gustina, 2018) sehingga diharapkan secara tidak langsung berkorelasi nyata dengan libido dan kuantitas semen, tetapi hal tersebut tidak diperlihatkan pada sapi silangan Friesian Holstein (FH) dengan Tharparkar (Rajak et al., 2014) dan sapi pasundan pada penelitian ini. Konsentrasi testosteron yang berkorelasi rendah dan bersifat negatif terhadap konsentrasi sperma pada penelitian ini dimungkinkan karena 
Tabel 1. Konsentrasi testosteron, umur, lingkar skrotum, libido dan kuantitas sperma sapi pejantan pPasundan

\begin{tabular}{lcccc}
\hline Parameter & $\mathrm{n}$ & Mean $\pm \mathrm{SE}$ & Minimum & Maksimum \\
\hline Testosteron (ng/mL) & 10 & $13,38 \pm 0,21$ & 12,9 & 13,85 \\
Umur (bulan) & 10 & $77,18 \pm 6,51$ & 62,45 & 91,91 \\
Lingkar skrotum (cm) & 10 & $30,10 \pm 1,39$ & 26,96 & 33,24 \\
Courtship (detik) & 10 & $8,8 \pm 1,90$ & 4,5 & 13,1 \\
Mounting (detik) & 10 & $70,3 \pm 28,05$ & 6,85 & 133,75 \\
Ejaculation (detik) & 10 & $146,4 \pm 20,26$ & 100,57 & 192,23 \\
Volume semen (mL) & 10 & $6,67 \pm 0,89$ & 4,66 & 8,68 \\
Konsentrasi sperma $\left(10^{6} / \mathrm{mL}\right)$ & 10 & $790,9 \pm 65,64$ & 642,42 & 939,38 \\
\hline
\end{tabular}

Tabel 2. Korelasi antara umur, konsentrasi testosteron, libido dan kuantitas semen sapi pejantan pasundan

\begin{tabular}{lcccccccc}
\hline & HT & Umr & LSkr & Crt & Mnt & Ejc & VS & KS \\
\hline HT & 1 & 0,116 & 0,328 & $-0,661^{*}$ & 0,249 & $-0,179$ & 0,243 & $-0,116$ \\
Umr & & 1 & $-0,009$ & $-0,681^{*}$ & 0,215 & $-0,013$ & $-0,383$ & $-0,489$ \\
LSkr & & & 1 & $-0,353$ & 0,029 & $-0,231$ & 0,452 & 0,018 \\
Crt & & & & 1 & $-0,291$ & $-0,038$ & $-0,235$ & 0,382 \\
Mnt & & & & & 1 & $0,756^{*}$ & $-0,148$ & 0,333 \\
Ejc & & & & & & 1 & $-0,036$ & 0,425 \\
VS & & & & & & & 1 & 0,062 \\
KS & & & & & & & & \\
\end{tabular}

HT: Hormon Testosteron, Umr: umur, LSkr: lingkar skrotum, Crt: courtship, Mnt: mounting, Ejc: ejaculation, VS: volume semen, KS: konsentrasi sperma. Tanda * menunjukkan korelasi nyata $(\mathrm{P}<0,05)$.

tingginya kadar hormon testosteron yang mempengaruhi perkembangan sel spermatogonium. Penekanan konsentrasi testosteron dalam testis diperlukan untuk mendukung perkembangan sel spermatogonium (Haywood et al., 2003). Lebih lanjut dijelaskan bahwa efek tunggal testosteron pada tikus hypogonadal (hpg) tidak merangsang peningkatan jumlah sel spermatogonium. Hal ini juga didukung oleh hasil penelitian lain seperti terjadinya deplesi sel spermatogonium juvenile pada tikus mutan dan tikus yang telah diiradiasi (Hasbi dan Gustina, 2018).

Korelasi yang rendah $(\mathrm{P}>0,05)$ juga diperlihatkan antara umur dengan lingkar skrotum (-0,009), mounting $(0,215)$, ejakulasi ($0,013)$, volume semen $(-0,383)$, dan konsentrasi sperma $(-0,489)$. Hasil yang sama juga dilaporkan oleh Wiyanto et al. (2014) bahwa umur tidak berkorelasi dengan volume semen pada sapi simmental. Pada periode pertumbuhan dimana hewan berumur 12 bulan, maka koefisien korelasi antara umur dengan lingkar skrotum, volume semen dan konsentrasi sperma masih moderat. Selanjutnya ketika mencapai dewasa, koefisien korelasi akan meningkat dan akhirnya turun kembali pada usia lanjut (Zaid et al. 2019).

Tingkah laku seksual dan kemampuan ejakulasi pada pejantan dipengaruhi oleh bangsa, umur, genetik, libido dan lingkungan (Beran et al., 2011; Kondracki et al., 2013). Rehman et al. (2016) menyatakan umur sapi secara signifikan mempengaruhi libido dan kualitas semen pada sapi jantan jersey, $\mathrm{FH}$, sahiwal, achai, dan persilangan sahiwal dengan FH. Tetapi pada sapi simmental, umur tidak berpengaruh nyata terhadap volume (Wiyanto et al., 2014). Penelitian yang dilakukan oleh Ahmad et al. (2005) melaporkan pada sapi sahiwal berumur 36-60 bulan dan $>60$ bulan memiliki ukuran testis yang lebih besar dan berbeda signifikan dibandingan dengan sapi umur $<36$ bulan. Perbedaan dan pertambahan umur antar individu sapi umumnya menunjukkan pola yang meningkat (Wiyanto et al., 2014). 
Korelasi tinggi bersifat negatif $(\mathrm{P}<0,05)$ diperlihatkan antara konsentrasi hormon ($0,661)$ dan umur $(-0,681)$ dengan waktu courtship. Konsentrasi hormon yang lebih tinggi dengan umur pejantan yang semakin tua mengakibatkan waktu untuk courtship yang semakin singkat. Perbedaan waktu courtship pada sapi bali yang dilakukan oleh Knaofmone et al. (2019) akibat adanya perbedaan jarak tempuh pengukuran (5 meter) dan umur ternak yang digunakan. Hasil analisa regresi (Tabel 3) antara konsentrasi testosteron dengan courtship diperoleh persamaan garis regresi $\mathrm{Y}=-6,0044 \mathrm{X}$ + 89,113 dengan nilai koefisien determinan $\left(\mathrm{R}^{2}=0,4374\right)$ artinya konsentrasi testosteron akan memperngaruhi waktu courship sebesar $43,74 \%$. Persamaan regresi antara umur dengan courtship yaitu $\mathrm{Y}=-0,1991 \mathrm{X}+24,164$ dengan nilai koefisien determinan $\left(\mathrm{R}^{2}=0,4642\right)$ atau $46,42 \%$ waktu lamanya courtship dipengaruhi oleh umur pejantan.

Hasil korelasi rendah $(\mathrm{P}>0,05)$ ditunjukkan antara lingkar skrotum dengan libido $(-0,353$; $0,029 ;-0,231)$, volume semen $(0,452)$, dan konsentrasi sperma $(0,018)$. Muthiapriani et al. (2019) menyatakan bahwa lingkar skrotum tidak dapat digunakan untuk memprediksi volume semen dan konsentrasi pada sapi PO. Lingkar skrotum juga tidak memiliki korelasi terhadap konsentrasi sapi llimousin dan sSimmental dengan nilai koefisien korelasi sebesar 0,36 (Prayogo et al., 2013). Hasil berbeda dilaporkan oleh Saputra et al. (2017) dan Zaid et al. (2019) yang menyatakan bahwa lingkar skrotum berkorelasi positif terhadap volume semen dan konsentrasi sperma sapi bali serta konsentrasi sperma sapi aceh.

Muthiapriani et al. (2019) menyatakan bahwa peningkatan ukuran lingkar skrotum dan berat badan akan diikuti dengan meningkatnya konsentrasi sperma, persentase motilitas normal dan morfologi sperma. Ukuran testis yang besar mengasumsikan tubuli seminiferi yang lebih banyak sehingga akan menghasilkan jumlah sperma dan seminal plasma lebih banyak yang akan berpengaruh terhadap volume semen (Khairi, 2016). Pada sapi pasundan terdapat perbedaan individu yang terlihat pada nilai minimum dan maksimum (Tabel 1). Beberapa sapi mempunyai volume yang rendah namun mempunyai konsentrasi yang tinggi, sebaliknya ada sapi-sapi yang mempunyai volume semen yang tinggi namun konsentrasi rendah. Penelitian pada sapi bali menunjukkan terdapat variasi individu yang sangat besar pada volume semen yang dihasilkan oleh seekor pejantan. Variasi volume semen yang dihasilkan dapat dipengaruhi oleh kondisi jantan, organ reproduksi dan sekresi kelenjar aksesoris (Indriastuti et al., 2020).

Hasil pengamatan antara parameter libido, korelasi tinggi $(\mathrm{P}<0,05)$ hanya terjadi pada waktu mounting dangan waktu ejakulasi $(0,756)$. Korelasi yang berbeda nyata antara mounting dangan waktu ejakulasi menggambarkan pejantan dengan waktu mounting yang lebih lama akan membutuhkan waktu relatif lama untuk terjadinya ejakulasi. Analisa regresi antara mounting dengan ejakulasi (Tabel 3) diperoleh persamaan garis regresi $\mathrm{Y}=0,5459 \mathrm{X}$ $+108,02$ dengan nilai koefisien determinan $\left(\mathrm{R}^{2}=0,5712\right)$ artinya lama waktu terjadinya ejakulasi dipengaruhi oleh waktu mounting sebesar $57,12 \%$.

Korelasi rendah $(\mathrm{P}>0,05)$ terjadi antara libido (courtship, mounting, dan ejakulasi) dengan volume semen $(-0,235 ;-0,148 ;-0,036)$ maupun konsentrasi semen $(0,382 ; 0,333 ; 0,425)$. Libido tidak memiliki korelasi yang nyata terhadap volume semen serta konsentrasi sperma juga dilaporkan oleh Singh et al. (2015) pada sapi sahiwal dan Knaofmone et al. (2019) pada sapi bali. Perbedaan libido pada masingmasing bangsa sapi memungkinkan adanya perbedaan hasil. Perangsangan berulang dengan selang waktu antar rangsangan yang pendek dapat meningkatkan hormon gonadotropin sehingga menginduksi hormon testosteron untuk mengoptimasi proses spermatogenesis (Saputra et al. 2017).

Tabel 3. Analisa regresi linear performa, umur, konsentrasi testosterone, tingkah laku seksual dan kuantitas semen sapi pejantan Pasundan

\begin{tabular}{lcc}
\hline Korelasi Regresi & $\mathrm{Y}$ & $\mathrm{R}^{2}$ \\
\hline Konsentasi Testosteron dengan courtship & $\mathrm{Y}=-6,0044 \mathrm{X}+89,113$ & 0,4374 \\
Umur dengan courtship & $\mathrm{Y}=-0,1991 \mathrm{X}+24,164$ & 0,4642 \\
Mounting dengan ejakulasi & $\mathrm{Y}=0,5459 \mathrm{X}+108,02$ & 0,5712 \\
\hline
\end{tabular}


Volume semen dan konsentrasi sperma pada sapi pasundan berkorelasi rendah $(\mathrm{P}>0,05)$ yang bersifat positif sebesar 0,062 . Hasil yang sama dilaporkan oleh Rehman et al. (2016) pada sapi jersey, FH, sahiwal, achai, dan persilangan sahiwal-FH dengan nilai korelasi rendah sebesar 0,053 . Penelitian lain melaporkan bahwa volume semen tidak berkorelasi dengan konsentrasi sperma pada sapi madura dengan nilai korelasi 0,316 (Mayola et al., 2019). Singh et al. (2015) melaporkan hasil yang berbeda pada sapi sahiwal bahwa volume semen memiliki korelasi yang sangat nyata $(0,32)$ terhadap konsentrasi sperma. Semen terdiri atas sperma dan plasma dengan perbandingan $10 \%$ sperma dan $90 \%$ plasma (Indriastuti et al., 2020). Volume semen yang meningkat belum tentu diikuti peningkatan konsentrasi sperma karena bisa saja hanya jumlah plasma semen yang bertambah.

\section{SIMPULAN}

Konsentrasi testosteron dan umur memiliki korelasi yang tinggi dengan tingkah laku courtship, sedangkan volume semen dan konsentrasi sperma tidak berkorelasi terhadap konsentrasi testosteron, umur, lingkar skrotum maupun libido. Lama waktu terjadinya ejakulasi saat koleksi semen sangat dipengaruhi oleh lamanya waktu mounting.

\section{SARAN}

Pengukuran parameter reproduksi yang dimungkinkan saling berkorelasi sebaiknya dilakukan secara periodik ketika dilakukan koleksi semen terjadwal untuk melengkapi informasi data sapi pasundan. Hasil penelitian dapat digunakan dalam menganalisis perilaku individu pejantan dalam manajemen koleksi semen pejantan sapi pasundan sehingga dapat diperoleh kuantitas sperma maksimum.

\section{UCAPAN TERIMA KASIH}

Penulis mengucapkan terima kasih kepada Balai Inseminasi Buatan Daerah Ciamis Jawa Barat, Pusat Teknologi Produksi Pertanian Badan Pengkajian dan Penerapan Teknologi, dan Fakultas Kedokteran Hewan IPB University yang telah memberikan dukungan sarana dan prasarana pada pelaksanaan penelitian ini.

\section{DAFTAR PUSTAKA}

Affandhy L, Fitrayady HP, Luthfi M, Widyaningrum Y. 2018. Effect of live weight on libido, sperm quality, testosterone and luteinizing hormone in replacement stock of Ongole Grade bull. JITAA 43(4): 352-360.

Ahmad M, Asmat MT, Rehman NU. 2005. Relationship of testicular size and libido to age and season to Sahial bulls. Pakistan Vet J 25(2): 67-70.

Anwar P, Jiyanto. 2019. Identifikasi Hormon Testosteron Sapi Kuantan Plasma Nutfah Riau Sebagai Penentu Klasifikasi Kriteria Pejantan Unggul. J Petern Indonesia 21(3): 230-239.

Arifiantini RI. 2012. Teknik Koleksi dan Evaluasi Semen pada Hewan. Bogor (ID). IPB Pr.

Barth AD. 2018. Review: The use of bull breeding soundness evaluation to identify subfertile and infertile bulls. Animal (s1): s158-s164.

Beran J, Staìdniìk L, Duchaìcek J, Tousovaì R, Louda F, Stolc L. 2011. Effect of bulls' breed, age and body condition score on quantitative and qualitative traits of their semen. Acta Univ Agric Silvicul Mendel Brunen 5(6): 37 44.

Campbell JR, Campbell KL, Kenealy MD. 2003. Artificial Insemination: in Animal Sciences. $4^{\text {th }}$ ed. New York. Mc Graw-Hill.

Darussalam I, Arifiantini RI, Supriatna I, Rasad RSD. 2020. The effect of L-carnitine in Tris egg yolk-based diluent on the quality of Pasundan bull semen preserved in chilled condition. JITAA 45(3):197-205.

[Ditjennak] Direktorat Perbibitan dan Produksi Ternak. 2018. Roadmap Swasembada Pejantan Unggul 2018-2022. Jakarta. Direktorat Perbibitan dan Produksi Ternak, Direktorat Jenderal Peternakan dan Kesehatan Hewan, Kementerian Pertanian.

Eriksson P, Lundeheim N, Soderquist L. 2012 Changes in mean scrotal circumference in performance tested Swedish beef bulls over time. Acta Vet Scandinavica 54: 74.

Hasbi H, Gustina S. 2018. Regulasi Androgen dalam Spermatogenesis untuk Meningkatkan Fertilitas Ternak Jantan. Wartazoa 28 (1): 013-022. 
Hendri M, Riady G, Daud R. 2017. Hubungan Lingkar Skrotum dan Konsentrasi Spermatozoa pada Kambing Peranakan Ettawa (PE) Jantan. Jurnal Ilmiah Mahasiswa Veteriner 2(1): 41-50.

Herdis. 2012. Pengaruh Waktu Penampungan Semen Terhadap Gerakan Massa Spermatozoa dan Tingkah Laku Kopulasi Pejantan Domba Garut. J Sains dan Tekno Indonesia (14)1: 38-43.

Haywood M, Spaliviero J, Jimemez M, King NJC, Handelsman DJ, Allan CM. 2003. Sertoli and germ cell development in hypogonadal (hpg) mice expressing transgenic follicle-stimulating hormone alone or in combination with testosterone. Endocrinology 144: 509-517.

Hoflack G, Van Soom A, Maes D, Dekruif A, Opsomer G, Duchateau L. 2006. Breeding soundness and libido examination of Belgian Blue and Holstein Friesian artificial insemination bulls in Belgium and The Netherlands. Theriogenology 66(2): 207 216.

Indriastuti R, Ulum MF, Arifiantini RI, Purwantara B. 2020. Individual variation in fresh and frozen semen of Bali bulls (Bos sondaicus) Vet World 840-846.

[Kementan] Kementerian Pertanian. 2014. Keputusan Menteri Pertanian Nomor 1051/Kpts/SR.120/10/2014 Tentang Penetapan Rumpun Sapi Pasundan. Jakarta. Kementerian Pertanian.

Khairi F. 2016. Evaluasi Produksi dan Kualitas Semen Sapi Simmental terhadap Tingat Bobot Badan Berbeda. J Peternakan13 (2): 54-58.

Knaofmone E, Kune P, Uly K. 2019. Hubungan antara Tingkat Libido dan Berat Badan Pejantan Sapi Bali dengan produksi dan Kualitas Semen. J Petern Lahan Kering 1(3): $428-436$.

Komariah, Arifiantini RI, Aun M , Sukmawati E. 2020. Kualitas Semen Segar dan Produksi Semen Beku Sapi Pejantan Madura pada Musim yang Berbeda. J Ilmu Prod dan Tekno Hasil Petern 8(10) : 15-21.

Kondracki S, Iwanina M, Wysokinska A, Gorski K. 2013. The use of sexual activity measurements to assess ejaculatory performance of boars. Archiv Tierzucht 56(106): 1052-1059.

Mahmood SA, Ijaz A, Ahmad N, Rehman HU, Zaneb H, Farooq U. 2013. Studies on libido and serum testosterone concentration of cholistani AI bulls under stress free and stressful seasons. The Journal of Animal \& Plant Sciences 23(6): 1491-1495.

Maulana T, Said S, Arifiantini RI, Setiadi MA. 2019. Sex sorting sperm of sumba ongole bulls by using snakehead fish (Channa striata) albumin extract. JITAA 44(1):106113.

Menegassi SR, Barcellos JO, Peripolli P, Pereira PRR, Borges JB, Lampert V. 2011 Measurement of scrotal circumference in beef bulls in Rio Grande do Sul. Arq. Bras. Med. Veterinaìria e Zootec 63(1): 87-93.

Moghaddam G, Pourseif M, Asadpour R, Rafat SA, Jafari-Jozani R. 2012. Relationship between Levels of Peripheral Blood Testosterone, Sexual Behavior, Scrotal Circumference and Seminal parameters in Crossbred Rams. Acta Sci Vet 40(3): 1049.

Muthiapriani L, Herwijanti E, Novianti I, Furqon A, Septian WA, Suyadi. 2019. The estimation of semen production based on body weight and scrotal circumference on PO Bull at Singosari National Artificial Insemination Center. J Ilmu-Ilmu Petern 29(1) : $75-82$.

Nabilla A, Arifiantini RI, Purwantara B. 2018. Kualitas Semen Segar Sapi Bali Umur Produktif dan Non-Produktif Serta Penentuan Konsentrasi Krioprotektan dalam Pengencer Tris Kuning Telur. $J$ Veteriner 19(2): 242-250.

Nugraha DD. 2016. Karakteristik Kuantitatif Sapi Pasundan di Peternakan Rakyat. $J$ Ilmu Ternak Univ Padjadjaran 5(4): 1-10.

Perumal P. 2014. Scrotal circumference and its relationship with testicular growth, age, and body weight in tho tho (Bos indicus) bulls. Inter Sch Res Not. 1-6

Pineda MH, Dooley PM. 2003. Veterinary Endocrinology and Reproduction. $5^{\text {th }}$ ed. Iowa. Blackwell Publishing.

Prayogo KUE, Tagama TR, Maidaswar. 2013. Hubungan Ukuran Lingkar Skrotum 
dengan Volume Semen, Konsentrasi dan Motilitas Spermatozoa Pejantan Sapi Limousin dan Simmental. J Ilmiah Petern 1 (3): 1050-1056.

Qadarsina, Dasrul, Wahyuni S. 2019. Konsentrasi Hormon Testosteron Kerbau Simeulue dan Korelasinya dengan Tingkat Umur dan Lingkar Skrotum. J Agripet 19(1): 13-21.

Rachmawati L, Ismaya, Pudji Astuti P. 2014. Korelasi Antara Hormon Testosteron, Libido, dan Kualitas Sperma pada Kambing Bligon, Kejobong, dan Peranakan Etawah. Buletin Peternakan 38(1): 8-15.

Rajak SK, Tripathi UK, Attupuram NM, Boro P, Layek SS, Aslam MKM, A. Kumaresan A, Mohanty TK, Sreela L, and Prakash MA. 2014. Relationship of blood and seminal plasma testosterone concentrations with semen quality in crossbred bulls. Indian J. Dairy Sci 67(2): 162-167.

Ramaswamy S, Weinbauer GF. 2014. Endocrine control of spermatogenesis: Role of FSH and LH/ testosterone. Spermatogenesis 4 (2) : $1-15$

Ratnawati D, Isnaini N, Susilawati T. 2018. Character motility of liquid semen on Ongole crossbreed (PO), Bali and Madura bulls with different diluents at cold storage. Asian Jof Microl Bio Env Sci 20(1): 21-28.

Rehman H, Alhidary IA, Khan RU, Qureshi MS, Sadique U, Khan H, Yaqoob SH. 2016. Relationship of age, $\underline{b}$ reed and libido with semen traits of cattle bulls. Pakistan J. Zool 48(6): 1793-1798.

Sam AF, Pudjihastuti E, Hendrik MJ, Ngangi L, Raka IGPN. 2017. Penampilan Tingkah Laku Seksual Sapi Pejantan Limousin dan Simmental di Balai Inseminasi Buatan Lembang. J Zootek 37(2): 276-285.
Saputra DJ, Ihsan MN, Isnaini N. 2017. Correlation between the scrotum circle with cement volume, concentration and motility of bali beef spermatozoa. J of Trop Anim Prod 18(2): 59-68.

Senger Pl. 2012. Pathways to Pregnancy and Parturition. $3^{\text {rd }}$ ed. Pullman (US): Current Conceptions, Inc.

Sholikah N, Sutomo A, Widiasmoro NP, Wahjuningsih S, Yekti APA, Kuswati, Susilawati T. 2018. Hubungan Antara Tingkah Laku Seksual dengan Produksi Spermatozoa Sapi Brahman. Agripet 18(2): 67-73.

Singh S, Bhakat M, Mohanty TK, Kumar A, Gupta AK, Chakravarty AK, Singh P. 2015. Sexual behavior and its relationship with semen quality parameters in Sahiwal breeding bulls. Vet World 8: 745-749.

Smith LB, Walker WH. 2014. The regulation of spermatogenesis by androgens. Seminars in Cell \& Developmental Biology19(30):2-13.

Sorensen AM. 1979. Animal Reproduction. New York (US). McGraw-Hill Inc.

Wiyanto A, Yase Mas IK, Sutiyono B. 2014. Pengaruh Umur Terhadap Ukuran Testis, Volume Semen dan Abnormalitas Spermatozoa pada Sapi Simmental di Balai Inseminasi Buatan Ungaran. Anim Agricul $J$ 3(2): 292-299.

Zaid, Dasrul, Lubis TM. 2019. Corelation between age, scrotal circumference, and testis weight on concentration of spermatozoa in aceh bulls. J Medika Vet 13(2): 228-231.

Zulyazaini, Dasrul S, Akmal WM, Abdullah MAN. 2016. Karakteristik Semen dan Komposisi Kimia Plasma Seminalis Sapi Aceh yang Dipelihara di BIBD Saree Aceh Besar. Agripet 16(2): 121-130. 